\title{
Renata Dulian
}

Uniwersytet Papieski Jana Pawła II w Krakowie

\section{O CIERPIENIU I NADZIEI. RECENZJA KSIĄŻKI}

Cierpienie i nadzieja w twórczości filmowej Krzysztofa Zanussiego, pod red. A. Baczyńskiego, M. Drożdża i M. Legana, Wydawnictwo Naukowe Uniwersytetu Papieskiego Jana Pawła II w Krakowie, Kraków 2015, 385 stron, ISBN 978-83-7438446-9.

19 czerwca 2015 roku na Uniwersytecie Papieskim Jana Pawła II w Krakowie odbyła się uroczystość wręczenia Krzysztofowi Zanussiemu księgi jubileuszowej Cierpienie i nadzieja z okazji 75 rocznicy urodzin i 45 rocznicy debiutu filmowego. Redaktorami tomu są ks. Andrzej Baczyński, ks. Michał Drożdż i o. Michał Legan OSPPE, który prowadził to spotkanie. Uroczystość poprzedziła projekcja najnowszego filmu Krzysztofa Zanussiego Obce ciało.

Po projekcji filmu miało miejsce spotkanie z reżyserem. Uczestników tego spotkanie powitał ks. dr hab. Michał Drożdż, prof. UPJPII, dyrektor Instytutu Dziennikarstwa i Komunikacji Społecznej. Księgę jubileuszową wręczył jubilatowi rektor UPJPII ks. prof. dr hab. Wojciech Zyzak. Obce ciało wpisuje się konsekwentnie w „kino moralnego niepokoju”. W dyskusji podczas spotkania reżyser zastanawiał się nad wyborem między miłością do Boga a miłością do człowieka (jedna z bohaterek filmu, grana przez Agatę Buzek, pozostawia swoją miłość ziemską i wstępuje do klasztoru. Film pokazuje współczesną rzeczywistość, świat wielkich korporacji, stosunki tam panujące, degrengoladę moralną. Tom jubileuszowy otwiera przedmowa kard. Gianfranca Ravasiego, przewodniczącego Papieskiej Rady ds. Kultury, której Krzysztof Zanussi był konsultorem przez dwadzieścia lat. Kardynał zwraca uwagę, że śmierć, zło i wolność, wybór człowieka rozdartego między dobrem a złem, Bóg, miłość to dominujące tematy w twórczości reżysera. Jego filmy zmuszają do refleksji nad trudnymi tematami ludzkiej egzystencji, jak śmierć, sens cierpienia, utopia i transcendencja. Podkreśla rolę sztuki filmowej w przekazywaniu orędzia, przywołując słowa Jana Pawła II o roli, jaką pełnią w tym nowoczesne 
środki przekazu. Na treść tomu składają się refleksje znawców twórczości filmowej reżysera, analizujących jego dokonania. Mariola Marczak podejmuje temat zła i cierpienia w twórczości Krzysztofa Zanussiego. Adam Regiewicz dokonuje próby kerygmatycznej interpretacji jego filmów. Ks. Michał Drożdż w artykule Produkcja obrazu czy przesłanie wartości. Spór o etyczność stwierdza, że filmowcy powinny kierować się w swoich działaniach racjonalnością celów i źródeł, których prawdziwym sensem jest komunikowanie dobra i prawdziwych wartości. Dorota Narewska stwierdza, że w odniesieniu do filmów Krzysztofa Zanussiego można mówić o aktywnym poddawaniu się Ducha Świętego, o przechodzeniu od poznania rozdzielonego i szczegółowego do poznania ogólnego miłosnego. Piotr Pławuszewski pisze o filmach Zanussiego zrealizowanych podczas studiów w Państwowej Wyższej Szkole Teatralnej i Filmowej im. Leona Schillera w Łodzi. Grażyna Stachówna O śmierci prowincjała, dyplomowym filmie reżysera, który zdobył pięć znaczących nagród: w 1967 roku nagrodę PF DKF na Festiwalu Etiud PWSFTviT w Warszawie, Lwa św. Marka w kategorii filmów krótkich na Międzynarodowym Festiwalu Filmów Dokumentalnych w Wenecji, Złotego Dukata w kategorii filmów fabularnych do 60 minut na Międzynarodowym Festiwalu w Mannheim, w 1968 roku nagrodę na Festiwalu Etiud Studenckich WGIK w Moskwie za najlepszy film zagraniczny, Złotą Aurelię na Międzynarodowym Festiwalu Filmów w Valladolid. Piotr Sitarski analizuje dwa filmy: Ludzie licza (1954) i Komputery (1967), w których autorem scenariusza jest Krzysztof Zanussi (drugiego z nich także reżyserem). Oba filmy, zrealizowane w Wytwórni Filmów Oświatowych, analizując je w kontekście całej twórczości reżysera. Tomasz Kłys pisze o filmie Iluminacja z 1972 roku, Michał Dondzik o filmie Barwy ochronne z 1977 roku film ten analizuje również Mariola Dopartowa.

Marek Kotyński CSsR przedstawia Spiralę, zrealizowaną w 1978 roku. W obrazie tym reżyser podejmuje trudne pytania dotyczące sensu życia ludzkiego. Główny bohater Tomasz Piontek - dobrze sytuowany, niezależny mężczyzna w średnim wieku - dowiaduje się o nieuleczalnej chorobie. Po próbach leczenia, w ostrej depresji ucieka ze szpitala w Tatry i tam popełnia samobójstwo. Autor artykułu stwierdza, że Spirala pobudza widza do egzystencjalnej i metafizycznej refleksji, przygotowującej miejsce nadziei, która jest łaską Boga. Sławomir Bobowski pisze o scenariuszu Krzysztofa Zanussiego Śmierć pośrodku drogi, Joanna Preizner o nagrodzonym Złotym Lwem na festiwalu filmowym w Wenecji Roku spokojnego słońca, Iwona Kolasińska-Pasterczyk o filmie Paradygmat z 1985 roku. Ks. Andrzej Dragula zastanawia się nad pytaniami Zanussiego o dobro i zło kontekście jego filmu Dotknięcie ręki. Ks. Marek Lis analizuje film Życie jako śmiertelna choroba przenoszona droga płciowa, stwierdzając, że film przedstawia realizm i dramatyzm umierania człowieka, wyraża nadzieję, że to, co jest nieuniknione, nie jest ostatecznością, poza śmiercią jest wciąż nieprzenikniona tajemnica.

Ksiądz Andrzej Luter dzieli się refleksjami dotyczącymi filmu Persona non grata. Tom zamyka artykuł o. Michała Legana OSPPE o filmie Obce ciało. Jest to analiza filmoznawczo-teologiczna, ukazująca dychotomię dwóch światów na przykładzie bohaterów tego filmu: Kris, symbolu świata transgresji i konformizmu, i klarownych postaci Kasi i Angela. Kasia, wybierając życie zakonne, staje się chroniona przed światem. Jak pisze autor artykułu, mur klasztoru jest symboliczną granicą porządkującą świat, stanowiącą odpowiedź na zniszczony przez przekraczanie (transgresję) świat pseudowolności, który prowadzi do zatarcia wszelkich granic, również tych człowiekowi najpotrzebniejszych. 